\title{
Innovative Design of Corporate Clothing in Tourism
}

\author{
Sonja Šterman \\ University of Maribor, Slovenia \\ sonja.sterman@um.si
}

Corporate clothing in tourism has characteristics that are distinct from other formal uniformed groups. This article deals with innovative approaches and the multifunctional design of corporate clothing in order to satisfy the needs of the end user. The research was limited to the corporate clothing used in the tourism sector, with a focus on accessories as part of corporate clothing, in this case on men's ties. One of the main questions was how to offer aesthetically pleasing and useful accessories for corporate clothing in the tourism sector, using a recognisable geographical symbol or a traditional story. The method of gathering and analysing information with the help of a survey, fashion design research, and design development was used. The purpose was to design men's ties that correspond to the requirements of users to offer youthful, relaxed, and innovative ties that reflect the identity of the company. The typical problems with wearing ties, which are uncomfortable and feel hot when worn, were considered. Development from the idea to the final product was a challenge, as well as the cooperation between the subscriber, the designer, the suggested manufacturer and the Faculty of Mechanical Engineering, University of Maribor; all needed to work together to satisfy the end user. A tie was developed in the shape of an innovative, buttoned band that could replace the traditional tie and give the user much more freedom when wearing it in different weather conditions. At the same time, the tie maintains the elegance expected of a traditional tie. The surface is using the unique technique of air lace, which includes storytelling in the design and personalisation in the making. The design took a sustainable approach, which results in the use of significantly less material. The combination of the above features represents an innovative approach to developing fashion accessories for corporate clothing design.

Keywords: corporate clothing, innovative accessories, multi-functionality, functional design, tie, tourism https://doi.org/10.26493/2335-4194.11.57-65

\section{Introduction}

Tourism workers are an essential part of the tourism system. They serve guests with their professionalism and kindness. With their visual appearance and their communication skills, they influence the experience of their guests. In this context, it is imperative that workers who are selling their knowledge, services, products, and capacities feel self-confident and comfortable in their uniforms. Successful communication also depends on their human capital (Kaluža \& Bojnec, 2016) from the point of view of clothing as non-verbal communication (Bernard, 2002). Corporate clothing with its style and colour has a significant impact on society and user acceptance (Adomaitis \& Johnson, 2005). Clothes should have a strong identity, transforming local features into visual information, in the form of lines 
and details that will activate tourists' senses and tell stories about the organisation, town, region, or country.

Appropriate functional clothing is comfortable and of high quality, thus enabling those wearing it to be focused on their important tasks and their working result and visual impact can be better. Inappropriate material, the design of the model, or incorrect sizing can disturb their work and lead to workers who are not focused primarily on their tasks. The same applies to accessories as a part of corporate clothing. If they are not appropriate, they can disturb the normal work process. Some accessories in corporate clothing have a more functional impact on clothing, such as a belt, while others, such as ties or scarves, have a more aesthetic impact.

The critical elements in the design are innovation and multi-functionality. Innovation is an attribute that is expected of every new product. Innovation can be expressed with new shapes, materials, colour combinations, the manner of making, or by way of use. McKelvey and Munslow (2003) see innovation as 'something that comes from thinking in different ways, having different approaches, by searching for something new' Functionality in corporate clothing is one of the most important criteria. With multi-functional design, a product can be used in many different ways.

As an example, we will present corporate clothing for the staff of Spirit Slovenia at the Expo Milano 2015 Trade Fair (Šterman \& Kreševič Vraz, 2017). The requirements of the client were clear: they would like their corporate clothing to reflect freshness and youth and had to provide free-moving, durable clothing with the possibility of home washing. In designing uniforms, we considered a design that has both an innovative multi-functional approach, and storytelling. We focus primarily on accessories that are often a part of the corporate clothing image. For women, scarves are very often used, and for men ties are commonplace. We would like to review the innovative solution for a man's tie, which was seen for the first time in the way it was presented here. It is a good solution for all the staff, working in similar conditions in Tourism, or other fields.

In this case, the starting point of research and de- sign were the needs of the users and their working conditions. We recognised users as young staff and their working conditions as described. Working in crowded areas in hot weather conditions demanded research into an innovative accessory that suited the user better than the traditional tie. We used innovative and multi-functional ideas and applied technical solutions for (buttoning and) wearing.

When designing for an international event, we intend to project a story about that country. In our case, it was Slovenia, and we were glad to introduce people to it. Local characteristics were presented in the unique design and included unique shapes and surfaces, with storytelling about local identity. Lines tell stories about different symbolic meanings: Slovenian symbols, cities, population density, local specialities, forests, rivers, and other features.

In this case, the stories in air lace accessories show that an innovative approach can give creative, functional and user-friendly results.

There were no limitations in the presented example, where all measurements from the shirt buttoning and from the tie are fitted. If someone would like to use that tie with another shirt, the buttoning probably will not fit completely. That is a technical challenge for the next version.

For every profession, it is necessary to consider starting points and requirements. For tourism workers, it is necessary to wear clothes that correspond to working conditions, and the include storytelling and functional design. We would like to explain how we can prepare aesthetically balanced, functional, and useful corporate clothing design, with emphasis on accessories, which includes powerful local stories.

The research question is: How can we implement an innovative approach and multi-functional design in corporate clothing, to satisfy the needs of the end user working in the tourism sector and, at the same time, implement the story of a specific area into the design?

\section{Literature Review}

Corporate Clothing and Dress Codes

Workers in different areas of work have different rules of wearing that are sometimes subordinated to the dress code, especially those who wear formal wear 
(Pisani, 2016). Other workers wear corporate clothing with personalised rules or the dress code of a company.

In defining why to wear uniforms, one answer is that (UniFirst, 2017):

a uniform promotes a consistent brand image, identifies employees, and can convey many things, from a position of authority to a level of service. Uniforms evoke assumptions and associations about the wearer. It is important to understand how uniforms affect consumers and their decision-making processes.

Companies and associations that would like to build a recognisable corporate identity through clothing often decide to adopt a policy of corporate clothing. Through clothing, they represent a membership of a group in society or a group of workers in a company (U T SA, 2017):

Consumers associate certain positive traits with uniformed employees. A uniform conveys a higher work ethic and instills in a consumer a greater sense of trust and confidence. When a consumer sees an employee in uniform, they feel that they receive a better product and higher quality of service.

The answers in a questionnaire (U T S A, 2017) show that $82 \%$ of the participants can more easily identify with workers that wear uniforms; $61 \%$ of them think that employees in uniforms increase their confidence in their ability to do their jobs; $57 \%$ think that if employees are in uniform, the product quality will be higher than if the employee is not in uniform; 55\% trust employees in uniform more than they trust employees not in uniform; $54 \%$ feel more comfortable explaining their purchase requirements to employees in uniform than to those not in uniform.

Corporate clothing, as one of many clothing systems, has symbolic communication with society (Bernard, 2005; Damhorst, Miller-Spillman, \& Michelman, 2005). It communicates through its style and colour, showing a person's role, status, affiliation with a group, and the position of that person in the group (Bernard 2005).
In the design of corporate clothing, many criteria must be considered using multi-criteria decisionmaking (Šterman, 2014). There are many essential factors needed for the optimal design solution. It is attained through the design of many models that are incorporated into the unified solution made from clothing, shoes, and accessories.

In designing, we very different conditions of work and weather conditions must be considered. End-user acceptance and feedback are the keys to deciding between different ways of design (Šterman, 2014). All information influences the process of choosing fabrics and style of design. Regarding different groups of uniforms, we can also conclude that, for example, uniforms for civil authorities, have entirely different requirements to uniforms for Tourism.

The statement that the product should be aesthetically acceptable and useful at the same time (Ljungberg \& Edwards, 2003) is critical in corporate clothing, especially for tourism, for which meeting people and communication to achieve the main results of a business plan are of crucial importance. The need for uniqueness in the tourism context (Čivre \& Kolar, 2014), and the area of corporate clothing for tourism workers, where design became a part of the storytelling in the tourism context should also be discussed.

\section{Ties as an Important Part of Corporate Clothing}

Ties and scarves belong to the broad group of accessories. They are worn for functional or aesthetic reasons, and the market is full of different kinds of accessories (Jersey, 2016), which are an essential part of styling in everyday use and as a part of uniforms. Ties complete the clothing image, stress parts of the body, or styling, and complement the wearer's look. In addition, the tie attracts the eye to the face (Pisani, 2011). Today, the tie is part of a traditional formal business suit in the corporate and political realms, and for very formal business opportunities and ceremonies. The tie is also part of the corporate clothing image, crucially so in Tourism.

The oldest historical example of a tie is found in ancient Egypt (Pisani, 2011). A rectangular piece of fabric tied around the neck was an important part of the Egyptian male's clothing image, as it indicated the 
social position of an individual. A similar example can be found in the Roman Empire, where accessories resembled today's ties. The development of the tie, as we know it today, began in Europe in the 17th century, when the French king Louis XIV founded the elite Equestrian Regiment La Royal Croate in Paris. Croats wore the white route, tied around the neck in a unique way. It was part of a military uniform and, at the same time, a recognisable sign. Then the 'Hravatian' or 'Croatian,' as they called the tie, began to appear in the Court of Versailles, though with certain style modification. The original canvas was replaced by silk, decorated with rich Venetian lace. Over the centuries, ties took on different symbolic meanings. The tie was quickly established as a symbol of culture and elegance in the bourgeois fashion of the time. At the end of the 19th century, a narrower version of the necktie was created and retained as an essential part of the men's wardrobe. Through various models and styles of tying, to this day, the tie has demonstrated both the individual's individuality and social position and has no other useful function (Pisani, 2011).

\section{When a Problem Became a Challenge}

\section{for the Innovative Approach}

Sometimes men do not feel comfortable wearing a tie at work. There are many reasons why. Some of them asserted that wearing a tie in hot weather makes them feel uncomfortable. If we consider the weather conditions of $35^{\circ} \mathrm{C}$, we can understand. If they loosen the tie, the look is even worse than if there was no tie. A waiter, if he does not wear a jacket or vest that fixes the position of the tie, can have an unpleasant situation with serving food while wearing a tie. This was the reason for this research: to find a way of more appropriate design for ties.

Corporate clothing must, first of all, be designed functionally. The designing process is, thus, more oriented to specific user requirements (Gupta, 2011), subordinated to comfort. Functionality refers to the wearing and caring of the item. Many authors have written about user-centred thinking and the designing process. The first writer that categorised people's needs in relation to design, and life itself, was Abraham Maslow (Parsons, 2009). Results of the research were concen- trated on psychological, safety, love, esteem, cognitive, aesthetic and self-actualisation needs. Nowadays, the trend in products, services, and experiences is to develop them in a way to be enjoyed by a broad audience, regardless of age or ability, and oriented towards user-centred and inclusive design.

One of the sustainable approaches to design is multi-functional design, according to which one model can be used in many different ways. Consumption and environmental impact will be reduced if we can use clothing in many ways. Multi-functionality is, thus, one of the principles of slow fashion (Niinimäki, 2010).

A model can be created from many parts. A variety of components can be used, separately or in different combinations, and the user can save space and have more pieces in one (Mollerup, 2001). This is modularity. In fashion design, this can be seen in the so-called 'onion' way of wearing, in which modular clothes detach and make many possibilities, according to the weather conditions.

This problem leads to the functional design idea about a detachable tie, that looks similar to the traditional tie, but, with its approach to different ways of use, solves the problem of fixed wearing without limiting movement. Thus, the context of wearing was solved. Regarding the surface of the tie, storytelling is still needed.

\section{Empathic Approach to Storytelling Design}

There have been many proceedings published relating to the number of ways in which people can become more emotionally attached to products (Parsons, 2009). Their relation to a product is different if they know something more about the product and can have an emotional connection with it. In this case, the product has no personal story, and people have no emotional attachment to it. If people are co-creators of the product, or the product relates to a person or event connected to the story of the product, the emotional connections to the product are stronger.

The emotional durability of a product impacts its duration of use and life cycle. Owners have a greater sense of care of products with an emotional connection (Parsons, 2009; Niinimäki, 2011). This kind of product is kept longer, in comparison to a product 
that is not personal or connected emotionally to the user. The longer life cycle of a product leads to less consumption, less energy used and, finally, less waste. This kind of design thus has a more sustainable impact. Authors (Niinimäki \& Koksinen, 2011) discuss this relationship, in which the 'empathic approach can be of primary importance in promoting sustainable product relationships by deepening current methods of understanding consumers' needs, values and emotions.'

If all aspects are considered when designing, products are created that take into account the wishes of the customer. We accept the visual and functional properties of the product. We understand the message through different shapes and lines, details and proportions. 'Products communicate with us through visual language' (Parsons, 2009). All these artistic principles communicate the product and its characteristics with a visual story that we translate into our feelings. The empathic approach includes storytelling as one of many principles of design. It is 'a method of creating imagery, emotions, and understanding of events through an interaction between a storyteller and an audience' (Lidwell, Holden, \& Butler, 2010). Storytelling can be oriented in two ways from the designer's perspective (Johansson, 2017): as input and output in communication. Storytelling represents powerful images and gives values more dynamic context (Fog, Budtz, Munch, \& Blanchette 2010) in different areas of work. Like in design, empathy is also used in photography to expose the main story (Laigneau, 2017). Laigneau writes about many different approaches to expose the main story in photography, but some of them can be very useful to compare with exposing the story in designing accessories. She exposes unique expressions of life, idiosyncrasies in the crowd, urban geometry and architectural lines, complementarity of colours and shapes, patterns and repetitive elements, which comprise a convincing story.

Storytelling is also an effective device for fashion design. Sung and Kwon (2009) state that 'a story used interactively is a powerful tool for attention, understanding, and change in both individuals and communities.' The story of clothing can be told through its colour, shape, detail, and textile patterns. Patterns often include local motifs, which is a critical part of tourism promotion. Some corporate clothing that includes certain motifs, colours or design, is typical of one area or country. Motifs are used especially for $\mathrm{t}$ shirts and accessories. The importance of local motifs is shown in the research that explores 'the communication of Australasian cultural motifs to overseas tourists through the production and sale of designer apparel' (Asplet \& Cooper, 200o). This example shows the importance of authenticity that derives from cultural heritage, as well as that of locally made textile articles.

In tourism, storytelling is included in four different fields: marketing, product development, interpretation, and tourists' recounting of their experiences (Turnšek Hančič \& Trdina, 2017).

\section{Methods}

Based on the research question, 'How can we implement an innovative approach and multi-functional design in corporate clothing to satisfy the needs of the end user?' we made the next steps through research. For the first question, 'What does innovative and multifunctional design mean?' we used methods of gathering and analysing information. We discovered that the question correlated to theory background, and, furthermore, was connected to corporate clothing and accessories.

For the question 'Why are these kinds of accessories used in tourism and how can we improve the user experience?' it was important to research and design with empathy, using a questionnaire. What does the user feel in certain weather conditions when wearing a uniform? How can he be elegant and relaxed when wearing a tie? The method of obtaining answers was fashion design research and developing design and prototypes. We obtained the users' opinion by conducting a survey.

The next research question we focused on was, 'How can attractive and useful corporate clothing with local stories be offered?' The method of solving that challenge was research in the area of the storytelling theory, and research of local characteristics. We discovered how to implement ideas and make them into products with innovative technical solutions. 
Challenging starting points and expected results required the inclusion of the mentioned methods. The procedure makes the concept and design of accessories in the frame of corporate clothing as a unified combination. The technical aspects require planning, and development of a prototype and its realisation in accordance with other parts of corporate clothing that correspond to the requirements of the subscriber (Spirit Slovenija, 2015). The process of realisation requires individual and team work, which has to be well planned and coordinated.

\section{Research}

Exposed National Identity in Storytelling Design

From research to design, we explored national and local stories and planned how to portray our own story on the surface of the tie. All models of corporate clothing are inspired by information received in the brief, and further research into the meaning and personal feelings gained from exploring the promotional titles of the Expo Milano trade fair ('Feeding the planet, energy for life') and Slovenian pavilion ('I feel Slovenia. Green. Active. Healthy!'), as well as the logo 'I feel Slovenia.'

The main words and associations from research represent a storytelling of design (Šterman \& Kreševič Vraz, 2017). The result of the research was to incline toward asymmetrical models, colour accent lines, cuts and cross-sections in the design of the clothes. This part was inspired by expressions: fields, food, greenness, activity, health. The colour green symbolised vegetation and the structures of nature as an accent, which can be used for accessories.

Accessories can be unique and personalised, so we included different stories of diversity in Slovenia. To portray them in the best way, we planned to make personalised designs. The paraphrases of structural and textural characteristics of the form of Slovenia were shown in accordance with the promotional titles of the fair and the Slovenian pavilion. Slovenian regions and individual features are portrayed in terms of terrain morphology, biotic diversity with forests, rural and urban areas connected logistically by the highway and railway networks, as well as river basins. It is national, as well as state symbolism. This leads to the creation of pieces that complete stories on the topic of Slovenia and express Slovenian identity; at the same time, they spread ethnographic heritage to the realm of modern interpretations and applications, which is an extremely important contribution to the mosaic of Slovenian culture and its image.

We also researched the use of informal materials and special techniques that are not often used in accessories, especially accessories corporate clothing. We chose threads used in the technique of air lace. Green fashion accessories, in the form of laces, are produced on the basis of sewing the water-soluble embroidery base with thread. When using a sewing machine, the embroidery basis has only a temporary function and is later removed. Thus, a minimalist record is created, which illustrates diverse impressions of students' views of Slovenia. Structures emerging from thread surfaces enable a 3D representation of the landscape and its characteristics in the area (Šterman \& Kreševič Vraz, 2017).

The idea of air lace accessories includes personalisation, uniqueness, and different stories about Slovenia. It was an engaging challenge for the students and employees of the Laboratory for Clothing Engineering, Physiology and Garment Construction, the Faculty of Mechanical Engineering, at the University of Maribor, who made the accessories, to represent their personal views about Slovenia.

\section{Innovative Approach to the Storytelling}

\section{Design of Ties}

Men's ties were made to coordinate with women's scarves as a part of a corporate clothing identity, but the ties were in another shape. Instead of the traditional tie, the story of an innovative approach and, considering of specifics and limitation of men's ties, results in an innovative model of a tie.

The tie for men is simple, effective and innovative. It is in the shape of a band, made with the technique of air lace. The first example in Figure 1 shows the air lace band, where local specialities are shown. The structure of seams clearly shows the symbolic meaning of the band. Slovenia is rich in wines; therefore the motif of the grape is clear and simple to portray this fact. The same band also has a symbol of wheat that communi- 


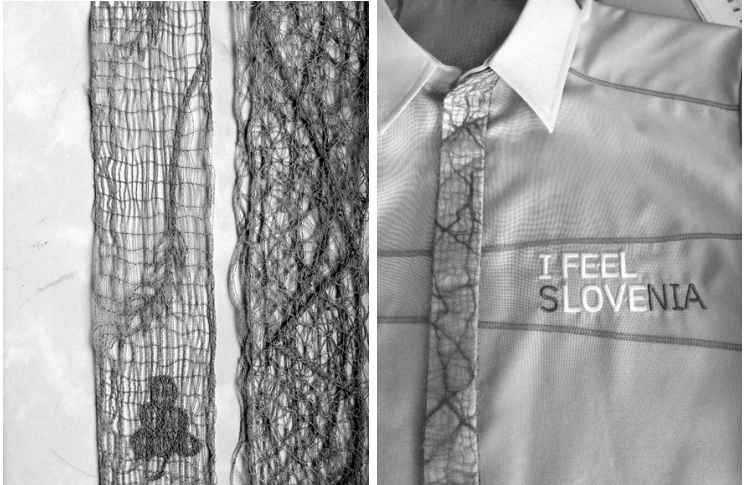

Figure 1 Examples of the Air Lace Bands with Stories (Left) and Buttoned on the First Prototype (Right) (Photo by Sonja Šterman)

cates that the north-eastern part of Slovenia is known as 'the breadbasket of Slovenia.'

The second example shows many lines that represent connections between people living in Slovenia. On the shirt, the tie shows a connection between cities in the region that was made under the map of traffic in Slovenia. The left example in Figure 2 is made with the map of the river basin of Slovenia. The right example from Figure 2 shows lines and borders of fields. All examples show that the local stories are an essential part of storytelling design and can be shown in very unusual and innovative ways.

The bands on the left part of Figure 1 present the upper level of the tie, that is, from the bottom side, finished with the fabric. That fabric has buttonholes at the same distance apart as on the shirt, so it could be simply buttoned onto the shirt (Figure 1).

The new model of a tie in this context could replace the traditional tie. The only condition to its use is that formality is not conditioned strictly to dress code. In Figure 2, we can see how innovative design can solve the problem of fixing the shirt and, at the same time, offer free movement by working in it.

Innovative variation of the men's tie (Figure 2) shows its composition from the top material - air lace - and material from the bottom of the shirt, which is, in our case, the same as the shirt. Photos were taken at the Expo Milano 2015 Fair, where this kind of tie was used for the first time.

\section{Discussion}

Corporate clothing in tourism often includes many accessories. Some have decorative functions, and some are part of the dress code or related to specific areas. We focused on men's ties, which are an excellent area of creativity, which can tell stories, be personalised and unique, and have an impact on the user, as well as other people connected in business. In this case, accessories overtake the role of nonverbal communication. As corporate clothing at the state level, they have to communicate the story of Slovenia: about regions, rivers, forests, symbols, cities, population density, and local specialities. They are made in innovative ways.

The starting point of the research was user requirements for appropriate corporate clothing that should look free and fresh, but also formal and innovative. When making a design, it is imperative to consider the working conditions of the staff. In our case, the staff had to work in hot weather conditions inside and outside of a pavilion. Accordingly, the design had to be functional and comfortable; therefore, a traditional tie was not an appropriate solution. Furthermore, the subscriber desired an innovative design representing a country. To tell a story about Slovenia was a challenging task. The research question asked how a strong identity using local features can be created. A unique storytelling design about local identity was included as the answer to the question of how to represent a story about Slovenia.

Besides the lines and materials of the corporate clothing, we decided to include innovative storytelling accessories. For men, we chose special ties. We used the air lace technique for accessories where the innovative approach gave a creative, functional and userfriendly accessory. Lines at the surface tell stories about different symbolic meanings: Slovenian symbols, cities, population density, local specialities, forests, rivers, and other features.

After considering all the data, we designed simple, effective, and innovative ties. As an answer to the requirements, we developed a variation of the tie that could be fixed onto the shirt at the bottom with buttons, and at the front, which was made as air lace. This band replaced the classical tie for men. With an innovative design, we have solved many problems: We of- 

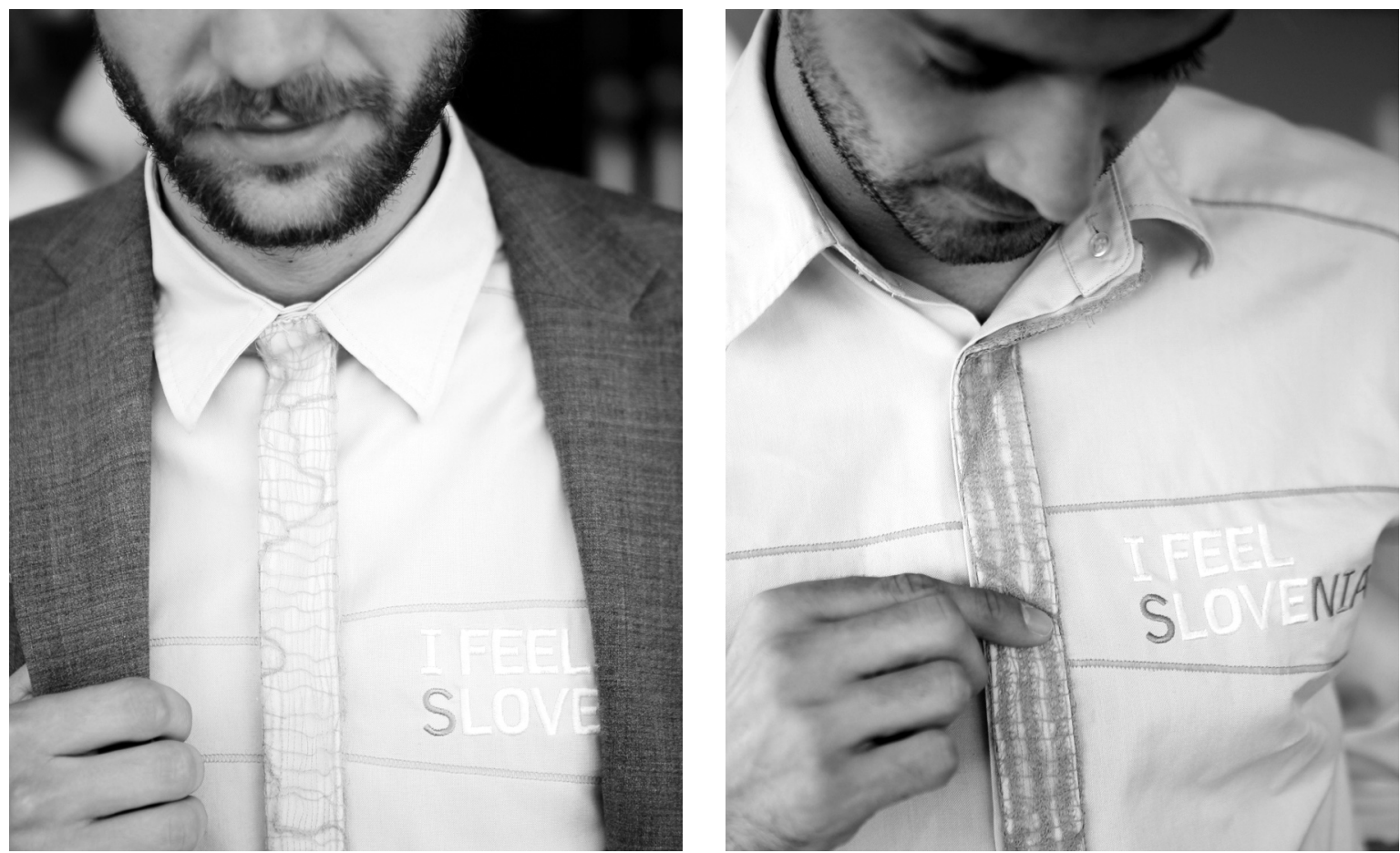

Figure 2 Staff of the Section Expo Milano in Corporate Clothing (Photo: Daniel Novakovič, STA)

fer freedom of movement when wearing a tie. The tie is fixed with buttons, and the shirt could be buttoned up to give a formal look. If the weather is too hot, the person is able to unbutton the shirt and leave it open for a more casual look. With the new design, we minimised the quantity of material in accordance with sustainable trends. From the historical point of view, we kept elegance and the impression of corporate clothing that still looks professional but, at the same time, personalised. This kind of tie is suitable for tourism workers and can solve technical problems of wearing ties in some other professions, where a dress code is not necessary.

\section{Acknowledgments}

In this case, we showed the successful collaboration of the subscriber Spirit Slovenia who chose the tendering company who developed and produced corporate clothing Moda Mi\&Lan d.o.o.; international connections were organised by the Republic of Slovenia, Government Communication Office; Studio design and the University of Maribor, Faculty of Mechanical Engineering. Collaboration between these parties allowed a pos- itive flow of knowledge, ideas, and experience. Every project is finished successfully when the end users are satisfied. In our case, the users gave positive feedback about the uniforms and the way they felt when wearing them.

I would like to thank the company Moda Mi\&Lan d.o.o. and the University of Maribor, the Faculty of Mechanical Engineering, Laboratory for Clothing Engineering, and the Lecturer S. Kreševič Vraz, Msc., who made the air laces shown in the Figures and mentored the students when they were making them.

I would like to thank J. Geršak for the support, and the colleagues and students for making the laces for the project which convey the original theme of the Slovenian presentation at Expo 2015: Rudolf, M. Abram Zver, S. Veličković, T. Podkrajšek, A. Firbas, A. Vajd, N. Šimunič, Š. Jerebic, A. Kožuh, A. Lilek, S. Emeršič, A. Đurinek, L. Spaskovič, K. Štampar, L. Görlichova, H. Vidmajer, N. Petkovič, J. Harb, M. Hudournik, M. Šumak, and T. Pompe.

\section{References}

Adomaitis, A. D., \& Johnson, K. K. P. (2005). Casual versus formal uniforms: Flight attendants' self-perceptions and 
perceived appraisals by others. Clothing and Textiles Research Journal, 23, 88-101.

Asplet, M., \& Cooper, M. (200o). Cultural designs in New Zealand souvenir clothing: The question of authenticity. Tourism Management, 21, 307-312.

Bernard, M. (2002). Fashion as communication. London, England: Routledge.

Čivre, Ž., \& Kolar, T. (2014). The relevance of consumers' need for uniqueness. Academica Turistica, 7(1), 35-45.

Damhorst, M., Miller-Spilman, K. A., \& Michelman, S. O. (2005). The meanings of dress: Dress in the workplace. New York, NY: Fairchild.

Fog, K., Budtz, C., Munch, P., \& Blanchette, S. (2010). Storytelling branding in practice. Heidelberg, Germany: Springer; Frederiksberg, Denmark: Samfundslitteratur.

Gupta, D. (2011). Design and engineering of functional clothing. Indian Journal of Fibre \& Textile Research, 36, 327-335.

Jersey, S. (2016). Corporate clothing 2016/2017: One uniform one team. Retrieved from https://issuu.com/ icommultiservicios/docs/simon_jersey_2016_catalogue

Johansson, L. (2017). Storytelling approaches in user experience design: How can storytelling benefit the designer? Retrieved from https://www.ntnu.no/documents/10401/ 1264433962/LinnArtikkel.pdf/e2f46529-abac-49d7-8e139b5oe3dao718

Kaluža, V., \& Bojnec, Š. (2016). Human capital and organizational climate in travel agencies. Academica Turistica, 9(1), 49-59.

Laigneau, M. (2017). Creating impact: The fundaments of storytelling in street photography. Retrieved from https: //issuu.com/marielaigneau/docs/creating_impact_by _marie_laigneau

Lidwell, W., Holden, K., \& Butler, J. (2010). Universal principles of design. Gloucester, m A: Rockport.

Ljungberg, L. Y., \& Edwards, K. L. (2003). Design, materials selection and marketing of successful products. Materials and design, 24(7), 519-529.

McKelvey, K., \& Munslow, J. (2003). Fashion design: Process, innovation \& practise. Oxford, England: Blackwell.

Mollerup, P. (2001). Collapsible. San Francisco, CA: Chronicle Books.

Niinimäki, K. (2010). Eco-clothing, consumer identity and ideology. Sustainable Development, 18(3), 150-162.
Niinimäki, K. (2011). From disposable to sustainable: The complex interplay between design and consumption of textiles and clothing (Doctoral Dissertations 84). Helsinki, Finland: Aalto University.

Niinimäki, K., \& Koksinen, I. (2011). I love this dress, it makes me feel beautiful! Empathic knowledge in sustainable design. The Design Journal, 14(2), 165-186.

Parsons, T. (2009). Thinking: Objects contemporary approaches to product design. Retrieved from: https:// issuu.com/jodyparra/docs/thinking-objects

Pisani, L. (2011). Obleka - kaj, kdaj, kako. Ljubljana, Slovenia: Author.

Pisani, L. (2016). Ravni oblačenja: $z$ nasveti za goste na televiziji, pogovor za službo, pogrebno slovesnost, poroko, maturantski ples, šolo. Ljubljana, Slovenia: Author.

Spirit Slovenija. (2015). Javno naročilo za oblikovanje in izdelavo uniform za osebje Spirit Slovenija na Expo Milano 2015. Retrieved from http://www.spiritslovenia.si/ razpisi/2015-01-23-Javno-narocilo-za-oblikovanje-in -izdelavo-uniform-za-osebje-SPIRIT-Slovenija-na -EXPO-Milano-2015

Sung, Y., \& Kwon, G. (2009). A study on establishing relationship between fashion design process and storytelling. The Journal of Fashion \& Textile Research Journal, $11(2), 210-218$.

Šterman, S. (2014). User evaluation of the waterproof jacket. Autex Research Journal, 14(1), 8-14.

Šterman, S., \& Kreševič Vraz, S. (2017). Inovativni pristup dizajniranju korporativne odjeće za osoblje tvrtke Spirit iz Slovenije. Tekstil, 66(1/2), 16-25.

Turnšek Hančič, M. \& Trdina, A. (2017, March 23-25). Fostering innovation top-down: The case of storytelling in Slovene tourism. Paper presented at the Encuentros/AIRTH 2017 Conference, Portorož, Slovenia.

UniFirst. (2017). The uniform advantage. Retrieved from https://www.unifirst.com/pdf/employee-uniform -advantage.pdf

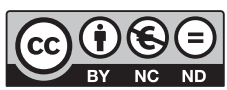

This paper is published under the terms of the Attribution- NonCommercial-NoDerivatives 4.0 International (CC BY-NC-ND 4.0) License. 